1725a. Gruber. Obamacare

https://doi.org/10.30953/tmt.v2.57

\title{
Obamacare: Coverage without Cost Containment
}

Page 1 of 13

David Gruber and Peter Urbanowicz

Editor's note: Changes (some predict repeal) in the Affordable Care Act is an immanent prospect that will affect all stakeholders in healthcare, including patients, providers, and innovators in telemedicine. In this article and three others included in this issue of Telehealth and Medicine Today, David Gruber and Peter Urbanowicz inform our readers and, hopefully, help prepare them for changes that may be every bit as impactful in 2017 as were the initiating events that occurred seven years ago on March $23^{\text {rd }}, 2010$.

In this series of articles in Telehealth and Medicine Today, we evaluate and grade Obamacare, speculate about the emerging Republican replacement plan and provide context to the evolving debate based on data-driven fundamentals of healthcare delivery. Likely "winners and losers" by stakeholder are also identified. Whatever the outcome of PPACA "repeal and replace," we believe that another reform debate, focused solely on health insurance coverage and payment for such coverage, will not adequately address the root cause of rising healthcare costs and attendant rises in health insurance premiums, i.e., an inefficient and ineffective care delivery system that on an age-adjusted per capita basis is $50 \%$ to $75 \%$ more expensive than that of other Organization for Economic Co-operation and Development (OECD) nations.

A quote from the esteemed Dr. W. Edwards Deming, the master of continual quality improvement, is appropriate: "It is not necessary to change. Survival is not mandatory." 
1725a. Gruber. Obamacare

https://doi.org/10.30953/tmt.v2.57

Page 2 of 13

Political pundits and health policy experts have stated what might appear to be obvious: eliminating coverage for more than 20 million Americans who have accessed coverage under the Affordable Care Act (ACA; Obamacare) without some replacement does not appear to be a tenable political or public health strategy. Several features of Obamacare such as the elimination of preexisting condition denials and household coverage of children under the age of 26 are among the most popular provisions of the Patient Protection and Affordable Care Act (PPACA) and, according to interview comments by President-elect Trump, are also likely to survive.

The proposed appointment of Congressman Tom Price, MD, the current Chairman of the House Budget Committee, as Secretary of Health and Human Services (HHS) has raised additional speculation about the future of healthcare policy in a Trump administration based on Congressman Price's prior statements about bureaucratic overreach into the practice of medicine. As Congressman Price re-introduced his own "repeal and replace" legislation in May 2015, it is clear that the new HHS Secretary has his own views about how to address and pay for individual insurance, how to deal with religious freedom issues (e.g., free coverage of birth control), the Children's Health Insurance Program (CHIP), Medicaid expansion and block grants, Medicare comparative effectiveness research and value-based purchasing, and medical malpractice reform.

Changes to the PPACA will not occur overnight. The legislation contains 2,700 pages; associated regulations represent another 20,202 pages. ${ }^{1}$ Repeal requires a vote by both houses of Congress. While the Republicans have a clear majority in the House to pass a repeal bill, Democrats can try to use the filibuster rules in the Senate to prevent a vote on a repeal bill, as bringing a full repeal bill to the Senate floor would require 60 votes. ${ }^{2}$ The Republicans could abolish or amend the filibuster or cloture rules in the new Senate, but that "nuclear option" seems unlikely. An alternative approach would be for Republicans to use the budget reconciliation rules, not subject to filibusters, to eliminate those portions of the ACA that can be eliminated through the reconciliation process. ${ }^{3}$ 
1725a. Gruber. Obamacare

https://doi.org/10.30953/tmt.v2.57

Page 3 of 13

But such a procedure would create a piecemeal "repeal and replace" process that might not immediately eliminate the most unpopular provisions of the PPACA.

In 2016, healthcare expenditures are forecast to approach \$3.4 trillion and represent $18.1 \%$ of the gross domestic product (GDP). The Centers for Medicare \& Medicaid Services (CMS) forecasts spending of $\$ 5.6$ trillion by 2025 , an increase of $\$ 2.2$ trillion within a decade. The federal government currently spends $\$ 646$ billion on Medicare and \$340 billion on its Medicaid contribution; state expenditures on Medicaid represent an additional \$205 billion. The Children's Health Insurance Program (Titles XIX and XXI), Department of Defense, Department of Veterans' Affairs, Indian Health Service, Substance Abuse and Mental Health Services Agency (SAMHSA) and other programs represent another $\$ 400+$ billion. In aggregate, $\$ 1.6$ trillion or nearly one-half of national health expenditures are funded by federal, state and local governments ${ }^{4}$

It is important to recognize that government involvement in the large and often dysfunctional U.S. healthcare delivery system has been longstanding since the inception of Medicare and Medicaid in $1965 .{ }^{5}$ The PPACA represents only one step, albeit an important one, in the evolution of care delivery. Any changes to the PPACA by the new Congress and Trump administration will represent the next iteration.

Prudent public policy formation would suggest that any repeal and replacement of the PPACA should take into account those provisions that have succeeded and those that have failed. Below we have attempted to provide a fact-based rationale for grading the impact of the PPACA on expanding healthcare insurance coverage and cost containment. We also grade access and affordability, variables that are intimately related to the implied benefit associated with insurance coverage.

The essence of Obamacare is coverage; the number of uninsured Americans declined by $35 \%$ from 41.0 to 28.5 million in 2013 to 2015 . This number is forecast to fluctuate no more than $+/-2$ million by 2025 , assuming no legislative or regulatory changes. 
1725a. Gruber. Obamacare

https://doi.org/10.30953/tmt.v2.57

Page 4 of 13

As of March 2016, more than 11 million people were enrolled in state or federal Marketplace plans, and as of June 2016, Medicaid enrollment had grown by more than 15 million (27\%) since the period before open enrollment (which started in October 2013). ${ }^{6}$ Note, however, that the health exchange participation figures are significantly below earlier CMS and Congressional Budget Office (CBO) expectations, which estimated that by 2016, 33 million Americans would be newly covered, with Medicaid enrollment exceeding expectation by 5 million and health exchange enrollment below expectation by 12 million. ${ }^{7}$

For the entire 2017 to 2026 period, the incremental federal spending for people who the PPACA made eligible for Medicaid coverage is projected to be $\$ 100$ billion per year, whereas the comparable figure for premium exchange subsidies is $\$ 90$ billion; in total, this equals $\$ 190$ billion in incremental federal healthcare spending per annum. ${ }^{67}$

Increased Medicaid and insurance coverage has somewhat increased provider access, especially relative to those who remain uninsured. Increased funding for Federally Qualified Health Centers (FQHC), combined with expanded hours at certain facilities, has helped. However, significant barriers to access to care remain for Medicaid beneficiaries and individuals with health exchange purchased insurance:

- Growing shortage of physicians, estimated by the American Association of Medical Colleges at 46,000 to 90,000 in $2025^{8}$

- Inadequate number of network providers, especially specialists in exchange plans and Medicaid

- Limited acceptability of Medicaid by physicians and non-physician providers

- Patients without an identified primary care provider

- Restricted availability of (timely) appointments

- Limited provider proximity and/or excessive transportation costs

Affordability of care is the major barrier to access. Rising out-of-pocket expenses driven by higher premiums, coinsurance, copayments and, especially, deductibles represent 
1725a. Gruber. Obamacare https://doi.org/10.30953/tmt.v2.57 Page 5 of 13

financial challenges to many Americans (Figure 1). The PPACA has contributed both to premium increases and higher copayments and coinsurance not only for Americans newly covered under the PPACA who are participating in exchange products, but for Americans who had already been covered by employer-based coverage or by their own individual insurance. Nearly three-quarters of households have income below $\$ 97,000$ per annum - the family of four maximum for health exchange subsidies. The average household income was $\$ 55,755$ in $2015 .^{9}$

\section{RISING OUT-OF-POCKET EXPENSES}

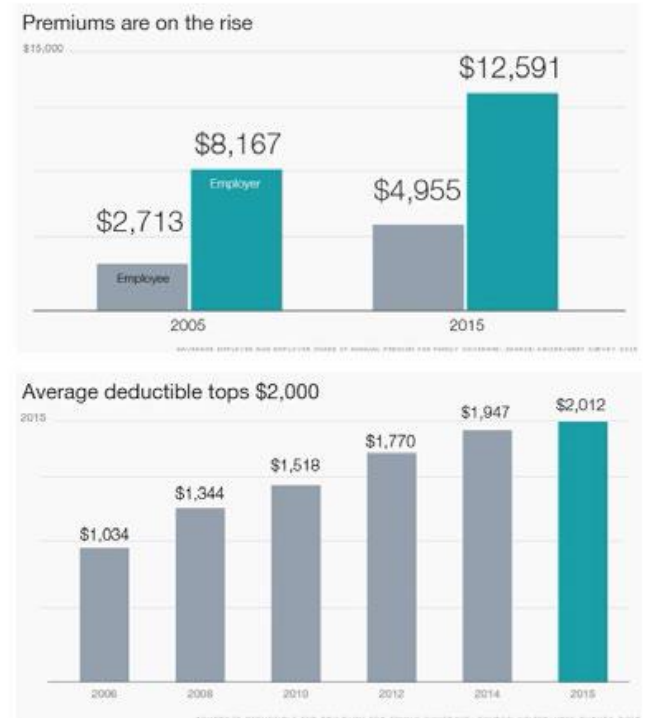

Source: Kaiser/HRET Survey, 2015
PERCENTAGE OF COVERED WORKERS ENROLLED IN AN HDHP/HRA OR HAS-QUALIFIED HDHP, 2006-2015

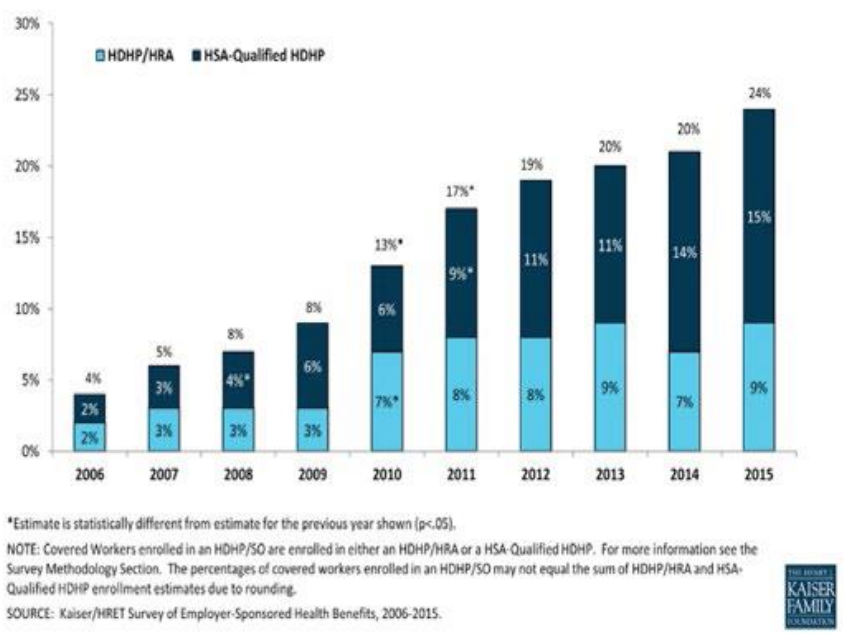

Figure 1. Affordability of care is the major barrier to access.

The Commonwealth Fund has developed a Health Care Affordability Index based on premium, deductible and out-of-pocket costs. One-quarter of all privately insured adults have high healthcare cost burdens. In a 2015 survey, 26\% of Americans described healthcare costs as causing a serious financial problem during the prior two years, $27 \%$ describe being unable to pay for basic necessities like food, heat or housing, and $42 \%$ mention spending all or most of their personal savings. ${ }^{10}$ Healthcare costs are a major contributor, if not the leading factor, associated with personal bankruptcy. 
1725a. Gruber. Obamacare

https://doi.org/10.30953/tmt.v2.57

Page 6 of 13

The affordability of insurance plans purchased on health exchanges, including those receiving premium subsidies, is also of concern. Premium costs are expected to rise $22 \%$ in 2017, during a period of declining choice as Aetna, United Health, and others have withdrawn from several major markets. Annual out-of-pocket payments of $\$ 7,150$ for individuals and $\$ 14,300$ are unaffordable for those ineligible for Medicaid and earning 1.4 to 4.0 times the Federal Poverty Level.

High out-of-pocket costs also adversely affect health outcomes due to the avoidance of necessary care (Figure 2.). High deductible plans, in theory, suggest greater selectivity of providers and the site of service. However, limited price and quality transparency, combined with inadequate patient literacy, may not result in the intended consequence.

\section{HIGHER COSTS AFFECT UTILIZATION OF HEALTH SERVICES}

Within the last 12 months, have you or a member of your family put off any sort of medical treatment because of the cost you would have to pay?

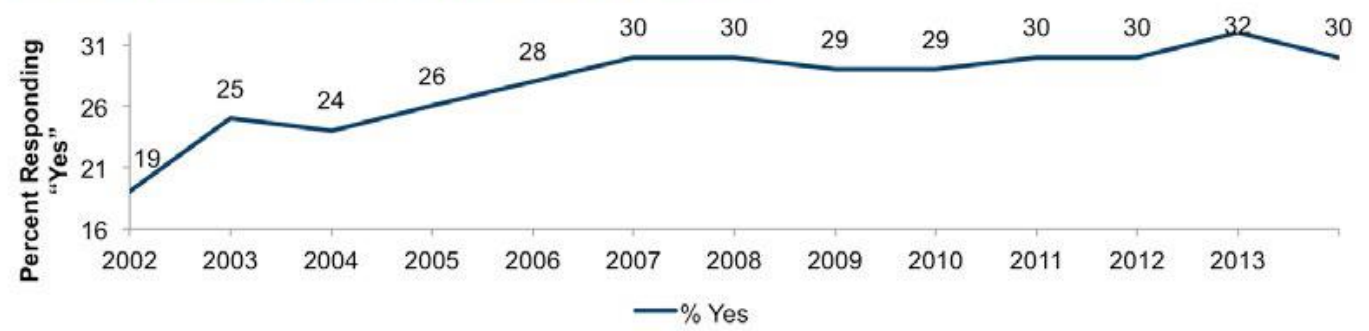

When you put off this medical treatment, was it for a condition or illness that was - very serious, somewhat serious, not very serious, or not at all serious?

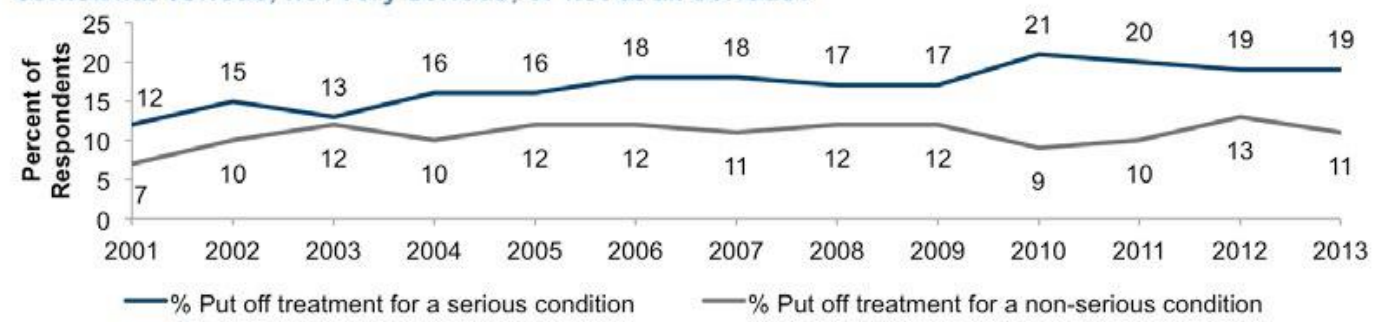

Source: GALLUP Well-Being. Costs Still Keep 30\% of Americans From Getting Treatment. December 9, 2013.

Figure 2. A Gallup Poll from 2013 suggests the possible occurrence of negative healthcare consequences in one-third of avoided visits. 
1725a. Gruber. Obamacare

https://doi.org/10.30953/tmt.v2.57

A December 2014 New York Times article entitled "Health Spending Rises Only Page 7 of 13 Modestly" highlighted 2013 as the year with the lowest rate of increase in healthcare spending (3.1\%) since recording began in 1960. ${ }^{11}$ One day earlier, the White House published the following statement on its blog: "Today's data make it increasingly clear that the recent slow growth in the cost of health care reflects more than just the 20072009 recession and its aftermath, but also structural changes in our health care system, including reforms made in the Affordable Care Act." 12

The celebration was premature and factually incorrect. Factors such as the Great Recession, significant cost shifting by employers and continued generic drug penetration led to the slowdown in healthcare spending; net structural changes instituted by the PPACA were inconsequential. In actuality, value-based CMS initiatives were more than offset by increased coverage, provider and insurer consolidation, and explosive growth in specialty and branded drug pharmaceutical pricing, thereby setting the stage for an acceleration of healthcare spending.

In 2014, overall health spending grew by $5.3 \%$, whereas per capita spending increased by $4.4 \%$ (Figure 3). The comparable figures for 2015 were 5.8 and $5.0 \%$, respectively. ${ }^{13}$ The latest projections from CMS forecast even higher growth through 2025. 
1725a. Gruber. Obamacare https://doi.org/10.30953/tmt.v2.57

Page 8 of 13

ACCELERATION OF NATIONAL HEALTH EXPENDITURES, 2014-15
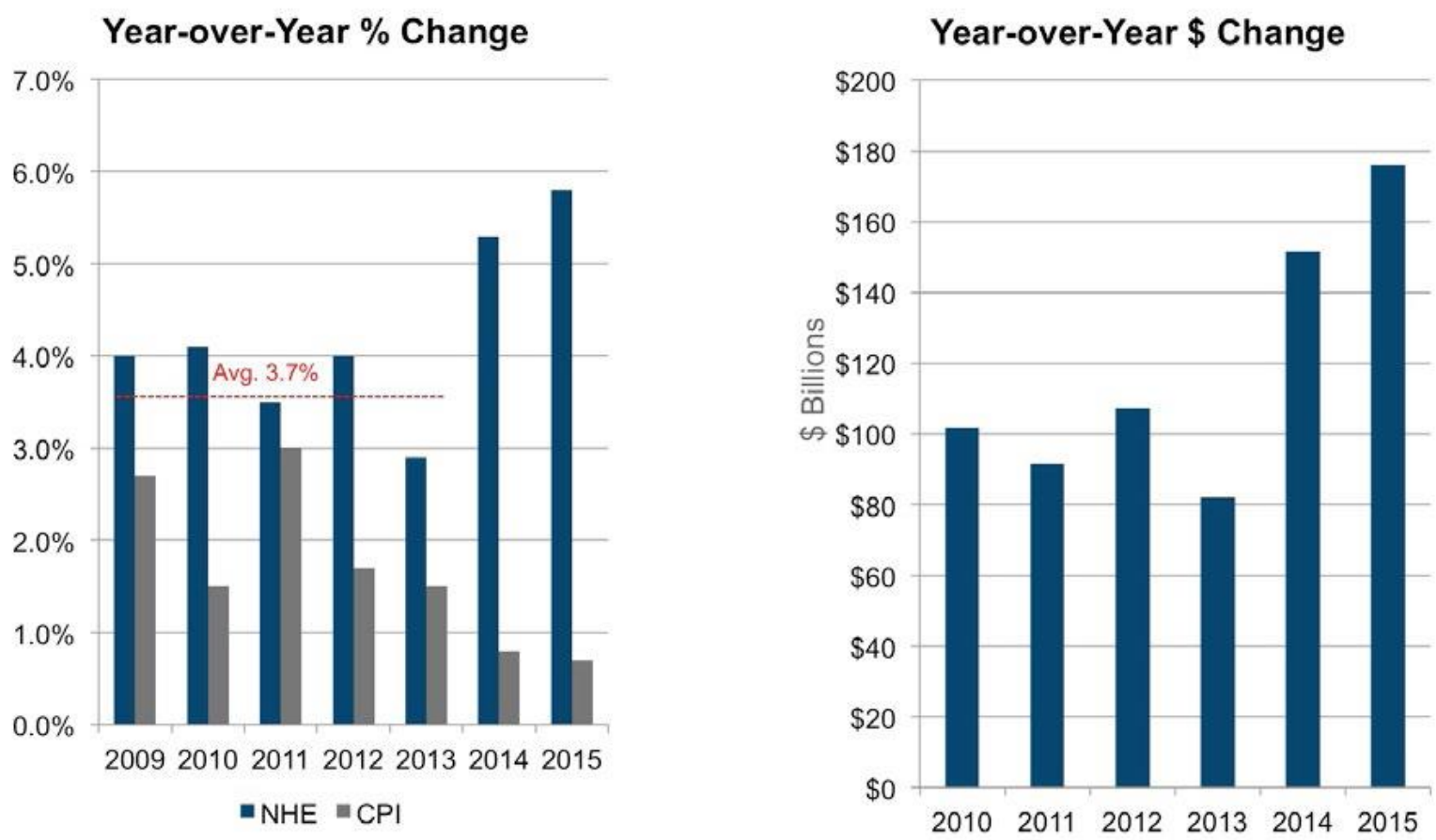

http://content.healthaffairs.org/content/early/2016/11/22/hlthaff.2016.1330.full.pdf+html; http:// www.usinflationcalculator.com/inflation/current-inflation-rates/

Figure 3. \% change and \$ change in healthcare expenditures 2009 to 2015.

Any discussion about healthcare cost containment is necessarily also a conversation about entitlement reform, the federal budget and the national debt. In 2016 to 2026, according to the CBO, mandatory federal outlays are forecast to increase from $\$ 2.5$ to $\$ 4.1$ trillion compounded annual growth rate (CAGR: 5.3\%), discretionary outlays from $\$ 1.2$ to $\$ 1.4$ trillion (CAGR: $1.8 \%$ ) and interest from $\$ 255$ to $\$ 830$ billion (CAGR: $12.5 \%$ ). Medicare ( $\$ 596$ billion) and Medicaid ( $\$ 261$ billion) alone account for $51 \%$ of the federal increase in mandatory outlays, whereas Social Security accounts for $42 \%$. A deficit of $-\$ 544$ billion in 2016 is forecast to reach $-\$ 1,366$ billion in 2026 , leading to an increase in the debt held by the public of $\$ 23.8$ trillion. ${ }^{14}$ Deficit spending and the subsequent rise in debt are unsustainable.

The CBO projections were generated prior to the November election. A report by the nonpartisan Committee for a Responsible Federal Budget estimates that tax reform 
1725a. Gruber. Obamacare

https://doi.org/10.30953/tmt.v2.57

Page 9 of 13

plans proposed by candidate and now President-elect Trump would, during the next decade, reduce individual and business taxes by $\$ 4.5$ trillion and increase the deficit by $\$ 5.3$ trillion; the debt held by the public would reach $105 \% .{ }^{15} \mathrm{~A}$ fact-based rationale for grading the impact of Obamacare is presented for the following areas (Table 1):

- Managing competition: Consolidation, as measured by standard measures of competition such as the Herfindahl- Hirschman Index $(\mathrm{HHI})$, leads to higher baseline prices and portends a higher rate of spending growth in the future.

- Increasing clinical effectiveness: Defined as the application of the best knowledge, derived from research, clinical experience and patient preferences to achieve optimum processes and outcomes of care for patients. Systematic reviews-the basis of evidence-based medicine-can show which treatments and prevention methods have been proven to work and what remains unknown.

- Improving efficiency: A measure of the relationship between a specific level of healthcare quality and the resources (intensity) used to provide that care, i.e., the production of the desired effects or results with minimum waste of time, effort or skill.

- Facilitating payment reform: Involves the use of financial incentives and disincentives to facilitate the transition from fee-for-service (FFS) payment models-providers receiving a specific amount of compensation in exchange for providing a patient with a specific service-to value-based payment systems focused on the provision of high-quality, efficient care.

- Enhancing the experience of care: Reflects occurrences and events that happen independently and collectively across the continuum of care. Embedded within patient experience is setting expectations, focusing on the specific needs of individual patients, and engaging patients and their caregivers. In all of these areas, the record is mixed, if not overall negative. In large part, the PPACA has led to a consolidation of providers and payers, with resultant increased prices. PPACA initiatives have shown only modest impact on clinical outcomes and overall improvements in the health of the general population. Although the PPACA created some new payment models (Accountable Care Organizations) and furthered Medicare's value-based purchasing initiatives, the record on 
1725a. Gruber. Obamacare

https://doi.org/10.30953/tmt.v2.57

Page 10 of 13

improving efficiency or payment models is negative to mixed. Finally, preliminary data suggests that the PPACA has not increased overall patient / consumer satisfaction with the healthcare delivery system.

\section{Table 1. Grading the impact of Obamacare}

\section{GRADING "OBAMACARE" (2)}

\begin{tabular}{|l|l|l|}
\hline & Grade & Rationale \\
\hline Managing competition & C- & Declining. Consolidation of payers, providers and suppliers raising prices \\
\hline $\begin{array}{l}\text { Increasing clinical } \\
\text { effectiveness }\end{array}$ & C & $\begin{array}{l}\text { U.S. has a shorter life expectancy; and higher (a) infant mortality (b) } \\
\text { maternal mortality } @ \text { ischemic heart disease mortality (d) lower extremity } \\
\text { amputations for diabetes } € \text { potential years of life lost and other metrics }\end{array}$ \\
\hline Improving efficiency & D & $\begin{array}{l}\text { Poor. Waste estimated at 10-30\% of total spending due to unnecessary } \\
\text { procedures, price variation, excessive administration costs, missed } \\
\text { prevention opportunities, fraud and other factors }\end{array}$ \\
\hline $\begin{array}{l}\text { Facilitating payment } \\
\text { reform }\end{array}$ & B- & $\begin{array}{l}\text { Multiple CMS initiatives "kick-start" shift from fee-for-service to value- } \\
\text { based care; episode payment models (e.g., CJR) a major step forward }\end{array}$ \\
\hline $\begin{array}{l}\text { Enhancing the } \\
\text { experience of care }\end{array}$ & D & $\begin{array}{l}\text { Poor. Despite recent efforts at hospital patient satisfaction (HCAHPS), } \\
\text { care delivery remains fragmented with limited care coordination, patient/ } \\
\text { caregiver understanding and engagement; payment (billing) remains } \\
\text { confusing. }\end{array}$ \\
\hline
\end{tabular}

1 OECD Health Data, 2015 and https://aneconomicsense. files,wordpress.com/2013/11/health-potential-years-of-life-lostper-100000-males-oecd-2011.png

${ }^{2}$ The Healthcare Imperative: Lowering Costs and Improving Outcomes, 2010 Table S-1. Adopted by National Academy of Sciences from IOM Workshop Summary.

In summary, the political rhetoric in Washington D.C. about the Accountable Care Act fails to fully capture the inefficiency and ineffectiveness of healthcare delivery, and the importance of payment reform (i.e., financial incentives) to change organizational behavior. Messaging, rather than fundamentals continues to drive the discussion. Healthcare is unaffordable for many, and the projected rise in spending is not sustainable.

David Gruber, MD, MBA is a Managing Director and the Director of Research with the Alvarez \& Marsal Healthcare Industry Group in New York, specializing in strategy, commercial due diligence, analytics and new ventures. Dr. Gruber brings 33 years of 
1725a. Gruber. Obamacare

https://doi.org/10.30953/tmt.v2.57

Page 11 of 13

diversified healthcare experience as a consultant, corporate executive, Wall Street analyst and physician.

Peter Urbanowicz, JD, is a Managing Director with the Alvarez \& Marsal Healthcare Industry Group in Washington, D.C., and leads the firm's healthcare compliance practice. He was formerly deputy general counsel of the United States Department of Health and Human Services and then general counsel of Tenet Healthcare Corporation (NYSE: THC). Mr. Urbanowicz has 25 years of experience in addressing challenging healthcare issues in government and private industry.

"Reprinted with permission, (C) 2016 Alvarez \& Marsal Holdings, LLC. All rights reserved. For more information, visit www.alvarezandmarsal.com."

Articles in this series can be accessed here.

Obamacare: Coverage Without Cost Containment

"Trumpcare": What's Next

Grading Obamacare on the Fundamentals of Care Delivery

Winners and Losers in "Trumpcare"

References

1. Kessler G. How many pages of regulations for Obamacare? May 15, 2013.

https://www. washingtonpost.com/blogs/fact-checker/ post/how-many-pages-ofregulations-for- Obamacare/2013/05/14/61eec914-bcf9-11e2-9b09-

1638acc3942e_blog.html?utm_term=.8922e72104f5

2. United States Senate. Filibuster and Cloture.

http://www.senate.gov/artandhistory/history/

common/briefing/Filibuster_Cloture.htm

3. Chait J. Repeal and Delay: The Republican Plan to Destroy Obamacare. New York Magazine. November 16, 2016. http://nymag.com/ 
1725a. Gruber. Obamacare

https://doi.org/10.30953/tmt.v2.57

Page 12 of 13

daily/intelligencer/2016/11/repeal-and-delaythe- republican-plan-to-destroy-

Obamacare. html

4. CMS National Health Expenditures. https:// www.cms.gov/Research-Statistics-Dataand-Systems/Statistics-Trends-and-reports/ NationalHealthExpendData/NationalHealthAccountsProjected.html.

5. Social Security. Vote tallies for passage of Medicare in 1965.

https://www.ssa.gov/history/tally65.html

6. Kaiser Family Foundation

7. Congressional Budget Office. Estimates for the insurance coverage provisions of the Affordable Care Act updated for the recent Supreme Court decision. Table 3; July 2012. https://www.cbo.gov/publication/51385

8. https://www.aamc.org/newsroom/newsreleases/ 426166/20150303.html 9.

https://www.census.gov/content/dam/Census/library/publications/2016/demo/acsbr1 5- 02.pdf

10. NPR / Robert Wood Johnson Foundation / Harvard T.H. Chan School of Public Health poll "Patients' Perspectives on Health Care in the United States." Interviews were conducted via telephone (landline and cellphone) in English and Spanish.

Sept. 8-Nov. 9, 2015. http://www.npr.org/sections/healthshots/ 2016/03/08/468892489/medicalbills- still-take-a-big-toll-even-with-insurance

11. New York Times. Health Spending Rises Only Modestly; Dec. 4, 2014. https://www.nytimes. com/2014/12/04/us/pace-of-healthcare- cost-increases-fallsto-a-54-year-low. html?_r=0

12. White House Blog; Council of Economic Advisers; Dec. 3, 2014.

13. http://content.healthaffairs.org/content/early/ 2016/11/22/hlthaff.2016.1330

14. The Budget and Economic Outlook: 2016 to 2026. https://www.cbo.gov/sites/default/ files/114th-congress-2015-2016/reports/ 51129-2016Outlook.pdf

15. Committee for a Responsible Federal Budget. http://crfb.org/papers/promises- andprice-tags-preliminary-update 
1725a. Gruber. Obamacare https://doi.org/10.30953/tmt.v2.57 Page 13 of 13

Category: Commentary

Tags

Affordable Care Act, clinical effectiveness, competition, Congressional Budget Office, efficiency, experience of care, grading Obamacare, Gruber, health spending, healthcare consequences, healthcare cost containment, healthcare delivery system, healthcare expenditures, Medicaid, Medicare, Obamacare, Obamacare, payment, Urbanow 